\title{
Intention to Quit of Proactive Health Workers: The Intervening Role of Employee Engagement and the Moderated Mediating Effect of Job Autonomy
}

\author{
Paul Dung Gadi ${ }^{1}$, Gontur Silas ${ }^{2}$ and Esther Bagobiri ${ }^{3}$ \\ ${ }^{1}$ Plateau State Polytechnic Barkin Ladi, Nigeria \\ ${ }^{2}$ Federal College of Education Pankshin, Plateau State, Nigeria \\ ${ }^{3}$ Kaduna State University, Nigeria \\ ${ }^{1}$ Email: jsstature@gmail.com
}

\begin{abstract}
As a necessary condition for the sustainability and success of teaching hospitals, maintaining proactive health personnel with the ability to be high performers is acknowledged. A few studies have logically clarified and empirically simplified the relationship between proactive employees and intention to quit, which signifies an engaged, proactive tendency to establish actual turnover behavior. However, this study target to resolve these research gaps. This paper predicted that the correlation between proactive health workers and intention to quit was likely mediated by employee engagement and job autonomy as a center point mechanism of motivation. Job autonomy (JA) as a significant framework is expected to buffer the link between proactive health employee and employee engagement. The present article developed a moderated mediated model that incorporates these variables. This study was consistent with previous studies carried out on health workers in Nigerian teaching hospitals. The results of this research help to expose the attrition intentions displayed by conscientious health workers.
\end{abstract}

Keywords: Proactive Worker, Intention to Quit, Employee Engagement, Job Autonomy

\section{How to Cite:}

Gadi, P. D., Silas, G., and Bagobiri, E. (2022). Intention to quit of proactive health workers: the intervening role of employee engagement and the moderated mediating effect of job autonomy. International Journal of Business, Management and Economics, 2(4). 1- 18. DOI: https://doi.org/10.47747/ijbme.v3i1.473

\section{Introduction}

Organizational members' turnover leads to a shortfall of social and human capital, which has a detrimental influence on organizational productivity (Tziner \& Birati, 1996). When high performers who make a significant contribution to an organization quit, the impact of the loss is substantially greater (Fuller \& Marler, 2009). For the reason that energetic personnel strive to initiate good behavior instead of adapting to unfamiliar situations that leads to changeoriented goals (Bateman \& Crant, 2017). Proactive personnel developed into high-achievers 
who exercise control over their environs and make every effort for significant change (Bakker et al., 2012). As a result, retaining active people with the ability to be high achievers is considered as a necessary prerequisite for an establishment's continued existence and growth (Bergeron et al., 2013). Thus, determining whether or not proactive people of a company will depart and how to keep those individuals is critical.

Researchers discovered that when employees want to leave a company, they tend to plan ahead instead of leaving on the spur of the moment (Bateman \& Crant, 2017). As shown in a meta-analytic assessment, their intention to quit has a strong explanatory power among the characteristics predicting their actual turnover behavior (Griffeth et al., 2000). As a result, the concept of turnover intention has been emphasised. Furthermore, an employee's proactivity, also known as proactive personality (PP), refers to the tendency to take action to increase efficiency and effectiveness (Bateman \& Crant, 2017). As a result, the likelihood of proactive personnel leaving appears to be explained by the associate between proactive personality and intention to quit. Furthermore, only few researches that have looked into the link between these two constructs in depth. Many previous investigations revealed the relationships between them without providing a theoretical justification. In the literature, there have also been some inconsistencies. Some researchers have discovered, for instance, that proactive personality (PP) is associated with a lower likelihood of quitting (Wang et al., 2011), others, on the other hand, have shown a link between proactive behavior and intention to quit (Vandenberghe \& Ok, 2013). Another research has found a statistically negligible link between the two (Allen et al., 2005). These inconsistencies suggest that the correlation between proactive personality (PP) and intention to quit may be more challenging as previously thought.

To tackle these theoretical gaps, the researchers propose that additional study would ponder on the previous variables. To begin, it is crucial to investigate the methods via which proactive personality is linked to a desire to quit. Personality, as a distant trait, influences behavior through proximal states like motivation, as per distal-proximal paradigm (Barrick et al., 2009). As a result, we should investigate a psychological construct that provides substantial explanations of the integral of the relationship between proactive personality and quitting intentions (Mathieu \& Taylor, 2006). Job engagement has been considered as an indication of motivation in addition to happiness. Hence, this paper concentrated on the mechanism by which PP of employees is correlated to their intention to quit (Schaufeli et al., 2008). As a result, we propose that PP is associated with intention to quit indirectly via work engagement.

Secondly, based on the circumstances, the correlation between PP and work engagement (WE) may vary. Trait activation theory states that certain events stimulate a trait further than the others (Tett \& Burnett, 2003). Job autonomy is at the foundation of motivational work design techniques, and it improves the proactivity of job officers (Morgeson \& Humphrey, 2006). As a result, we focus on job autonomy as a crucial related component. Job autonomy is thought to buffer the link between proactive PP and WE in this present study.

Finally, an integrated approach is required to completely comprehend the correlation between PP and intention to quit in an attempt to postulate a further realistic understanding of the links. The theoretical model is based on the (JDR) job demands-resources framework of WE, 
that presumes which individual and job resources, either separately or together, envisage WE, which has a beneficial impact on work performance (Bakker, 2011; Bakker \& Demerouti, 2008). Individuals that rank extreme on positivity, resilience, self-efficacy, and selfconfidence, for example, are employees competent to organize their workplace resources and are typically more involved in their job, according to the framework (Bakker \& Demerouti, 2008). We used the framework as a theoretical model to investigate the indirect or mediating impact of personal resources and the desire to quit through work engagement, as well as the moderating influence of job resources in this link. Employees with personal resources are more likely to manage and affect their organization efficiently (Hobfoll et al., 2003), and proactive personalities are more likely to begin change and influence their surroundings (Bakker \& Demerouti, 2008), Personal resources and PP appear to play a related function. Furthermore, according to the work personality's theory, one of the usual job resources is job autonomy (Bakker \& Demerouti, 2008; Abdulrab et al., 2017; Kumdi et al., 2017; Gadi \& Kee, 2020a). As a result, we conclude that the (JDR) job demands-resources framework of WE aligns to the research hypothesis that proactive individuals will be further engaged at work and have a lower intention to resign if they feel autonomy in executing their jobs. As a result, we're trying to come up with a moderated mediation assumption that reports for job autonomy as the moderating environment and WE as the intervening mechanism in the link between PP and quitting intention.

The goals of this research are to see if WE mediates' the link between PP and intention to quit, if job autonomy (JA) moderates the relationship between PP and WE, and if JA moderates the mediated link between PP and intention to quit. Figure 1 depicts our study model that reflects these goals. These systematic and thorough methodologies are intended to aid in better understanding proactive employees' intentions to leave.

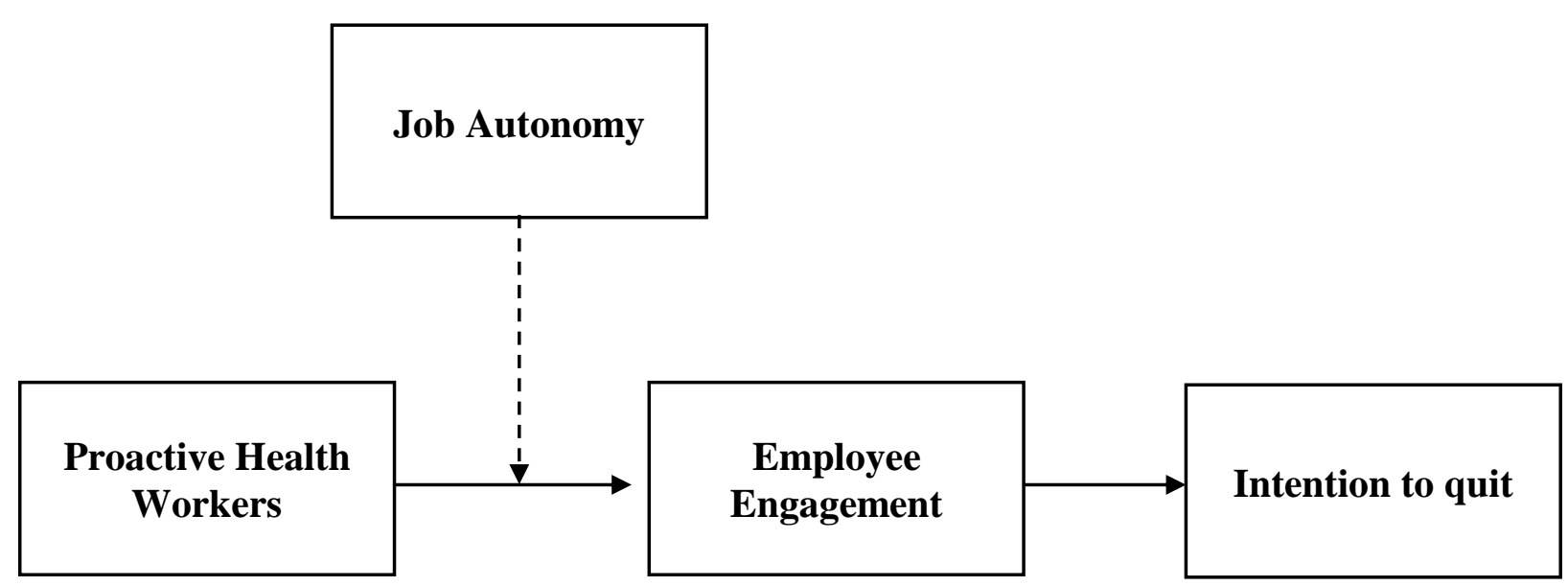

Figure 1. Research model

\section{Literature Review}

The study first look at the function of WE as a bridging factor in explaining proactive employees' intentions to leave. Furthermore, by concentrating on the increasing significance 
of JA in the link between PP and WE, we look at how engaged proactive employees are when they are given autonomy over their responsibilities. We also recommend using the integrated framework to fully comprehend the roles of job characteristic and emotional state in the relationship between PP and intention to quit.

\subsection{Mediating Role of Work Engagement (WE)}

This theory of job engagement arose from efforts to comprehend individuals' general psychological states, which ranged from sick to well. This was conceived as the polar inverse of burnout, which depicts a condition of exhaustion (Schaufeli et al., 2008). Recent research suggests, however, that WE is neither the polar inverse of burnout, nor is it fully independent of burnout (Jiménez et al., 2019; Schaufeli \& de Witte, 2017). In other words, work engagement has lately been recognized as having a negative link with burnout, but it also has its own set of characteristics (Jiménez et al., 2020; Gadi \& Kee, 2020b; Albadayneh \& Alrawashdeh, 2017). As a result, the problem is important to focus on not only to the qualities of WE that coincide with burnout, also to its unique personalities in order to comprehend the linkages between WE and other constructs.

Work engagement (WE) is seen as "an encouraging, satisfying, job-related state of viewpoint described by vigor (increased degrees of energy and psychological resistance whereas performing, likely to engage effort in one's job, and perseverance even in the face of difficulties), dedication, and perseverance even in the face of problems" (a sense of significance, enthusiasm, inspiration, pride, and challenge), and absorption (the state of being entirely absorbed and extremely immersed in one's task, in which time flies by and it is difficult to extricate oneself from it)" (Schaufeli et al., 2002). We use the distal-proximal technique, which states that distal employee dissimilarities have indirect impact on behavior via proximal employee dissimilarities, to explain how PP relates to intention to quit (Barrick et al., 2009; Caponecchia et al., 2020). We argue that WE is the intermediate mechanism that accounts for the relationship between PP and intention to quit.

Individuals with a high PP are likely to be very engaged with their job. "A stable propensity to take individual idea in a wide range of undertakings and jobs" is reflected in PP (Yang et al., 2017). Employees that are not proactive are less likely to "look for opportunities, not taking initiative, act, and endure to achieve closure by effecting about transformation" (Bateman \& Crant, 2017). They're also skilled at spotting or generating possibilities that will enable them to be more effective (Brito \& Oliveira, 2016). Individuals with PPs are further expected to have a strong, devoted, and absorptive technique to their job, and to make a significant contribution to the quality of their life at work. In light of this, researchers claim that "PPs is likely associated to engagement since persons that are immersed in their workplace are similarly inclined to engage themselves in their organization" (Vermooten et al., 2019). These findings show that having a proactive personality is linked to higher levels of job satisfaction (Bakker et al., 2012; Albrecht et al., 2015).

We also predict that engaged employees will have a lower likelihood of quitting. Burnout has long been thought of as a stressor and a contributing influence to high turnover (Kubayi, 2018). Job engagement is expected to reduce intention to leave because WE and burnout are philosophically and empirically opposites (Ugwu et al., 2013). In relation to this logic, it is vital to consider the characteristics of job engagement that distinguish it from burnout. Since 
engaged individuals are further energetic, passionate, and involved in their job, they are more likely to discover their job fundamentally engaging, to feel self-influenced to complete jobs, and to enjoy difficulties placed on them at work (Sheehan et al., 2019). Furthermore, employees manage to keep good psychological health devoid of feeling discomfort or sadness (Gupta et al., 2018), which would encourage them to stay in their current jobs and not leave. Consequently, assessed to disengaged individuals, engaged employees have further pleasant job knowledge and a stronger bond to their employers, which leads to a lower likelihood of quitting (Seibert et al., 2001; Ibrahim et al., 2019; Bakker \& Albrecht, 2018).

To summarize, proactive individuals are more liable to be involved in their job, which reduces their desire to leave. As a result, it's acceptable to assume that PP is associated to intention to quit indirectly via WE. We propose the following hypothesis based on this expectation:

Hypothesis 1 . Work engagement mediates the relationship between proactive personality and intention to quit.

\subsection{Moderating Role of Job Autonomy}

The researchers believe that the intensity of the link between an employee's PP and their WE will vary depending on the context. "Individuality traits are exhibited as reactions to trait that are applicable to environmental cues," according to trait activation theory (Muldoon et al., 2017). Similarly, innate attributes like personality are expressed in response to situational cues connected to the traits' characteristics. Given that the job serves as the primary link between employees and companies, it's important to concentrate on the job contexts in which they operate. Furthermore, because autonomy is a core job characteristic (Singh \& James, 2016; Beehr et al., 2001) and has the potential to stimulate employee proactivity (Tummers et al., 2015; Gruman \& Saks, 2011), job autonomy is expected to perform a vital situational cue in defining proactive employees' work engagement.

"The level to which a job gives independence, freedom, and pleasure to schedule work, make decisions, and choose the techniques utilized to execute tasks" is how job autonomy is defined (Singh \& James, 2016). Employees are open to perform their job activities based on individual decision and preferences when work is arranged in a manner that they have autonomy. Those who have a high amount of job autonomy are further expected to feel accountable for issues that develop while doing their duties and to recognize that they have sufficient influence over their employment outcomes (De Gieter et al., 2018).

Because jobs with more autonomy provide less limits on individuals' conduct, JA is more likely to act as a weaker factor, allowing individuality to steer performance directly. Given that PP stands for the individual predisposition to discover and act on chances for change, proactive individuals are capable to make use of autonomy as a way to handle professional requirements (De Gieter et al., 2018). (Bateman \& Crant, 2017). "To be proactive is probable very significant in positions with autonomy," according to academics (Bakker, 2017).

To summarize, proactive workers with autonomous occupations will have synergistic outcomes in that they will be further engaged in their organization. As a result, job autonomy is likely to reinforce the beneficial relationship between PP and WE. As a result of this anticipation, we suggest the following hypothesis: 
Hypothesis 2. The link between proactive personality (PP) and work engagement (WE) is moderated by job autonomy (JA), in a way that the correlation is stronger amongst individuals with high JA than individuals with low JA.

\subsection{Moderated Mediation Model}

This research shows that work engagement mediates the association between PP and intention to leave, and that JA moderates the link between PP and WE. These reasons, taken together, form a unified model in which JA heightens the motivational activities that underpin the PP and intention to leave link. To put it another way, the justifications for $\mathrm{H} 1$ \& $\mathrm{H} 2$ (Hypotheses 1 and 2) merge together to justify the incorporation of moderation and mediation, resulting in a mediation moderated framework (Malhotra et al., 2014; James \& Brett, 1984). In particular, proactive workers who do independent jobs are further expected to have prospects to perform in behaviors that are compatible with their proactivity, bolstering the mediating impact of WE in explaining the relationship between PP and intention to quit. The job demands-resources framework of WE underpins this assumption (Bakker \& Albrecht, 2018; Lartey et al., 2019). The approach believes that individual and professional resources are intertwined and relate to improve workplace engagement and outcomes. Personal resources, which are theoretically comparable to PP, refer to people's perceptions of their competence to successfully organize and influence their surroundings (Simon et al., 2015). One of the most common employment resources is job autonomy (Achmad et al., 2019). As the autonomy of proactive employees' duties grows, we expect their levels of job engagement to rise, and their willingness to depart from the organization to decrease. As a result of this anticipation, we suggest the following hypothesis:

Hypothesis 3. The mediated link between proactive personality (PP) and intention to quit through work engagement is moderated by Job autonomy (JA), in a way that the link is stronger amongst individuals with high job autonomy (JA) than individual with low (JA) job autonomy.

\section{Method Research}

\subsection{Procedure for Data Collection and Data Characteristics}

The study collected data from teaching hospitals in North-central Nigeria (Plateau, Nasarawa, Abuja, Niger, Benue, and Kwara). Teaching hospitals in Nigeria commonly encountered major employee turnover and voluntary withdrawal problems in the last five years (Nawaz et al., 2015). According to the Nigerian Medical Association (NMA), the average employee turnover ratio in the sector from 2016 to 2020 was $16.7 \%$ in teaching hospitals, and $15.4 \%$ in federal medical centers. As a result, it's important to look into the relationship between personal and job traits, as well as health workers' WE, and their intention to quit teaching hospitals in Nigeria.

A one-time field survey design was assumed. The research surveys were delivered to 1500 health workers using purposive sampling technique. There was a risk of data defect due to common method bias because the data was collected at a cross-sectional point based on health professionals' self-perception (Mackenzie \& Podsakoff, 2012). We placed the measurement scales of the key constructs (for example, Independent variable, mediator, moderator, and the dependent construct) separated by different scales of other extraneous constructs in the survey 
questionnaire, following the recommendation of past studies, to decrease any arbitrary inflation or deflation of relationships among variables (Mackenzie \& Podsakoff, 2012; Podsakoff et al., 2012).

The process for gathering data is as follows. The present study's objective and theoretical/practical contributions were first presented to the teaching hospitals' HR managers. The questionnaire began with a cover page that briefly described the study's purpose, besides problems of privacy and voluntary involvement, before moving on to the scales of psychometric properties and demographic questions. A total of 420 health workers took part in the survey, with a response rate of 38.92 percent. The conditional mean imputation approach was used to fill in a few missing variables. There was no abnormal case identified using a multivariate outlier identification technique based on Mahalanobis D2.

The present study's sample was drawn from a teaching hospital in North-central Nigeria; as a result, many demographic factors were used as control variables to exclude any false connections between the key variables. Gender, tenure, and education, according to prior research, may have a major impact on work engagement (Methot et al., 2016; Rai et al., 2019) and desire to resign (Methot et al., 2016; Rai et al., 2019). (Fabi et al., 2015; Memon et al., 2017). In all primary analyses, gender (female $=1$, male $=2$ ), tenure in yrs. at the present establishment, and education in yrs. (for instant, 17 years for a secondary-school graduate, 24 years for a university graduate) were mostly controlled.

\subsection{Measurement Scales}

The primary factors were measured using four psychometric instruments. All assessments were based on a five-point Likert scale, with 1 indicating strong disagreement and 5 indicating strong agreement.

The Proactive Personality Scale, in its abbreviated form, was used to assess proactive personality (Bateman \& Crant, 1993). Due to the high factor loading above (0.707), all six things were kept, and the mean of all the items was utilized in the main analysis. Three items from Morgeson and Humphrey (2006) were used to determine the level of job autonomy. The nine items of the work engagement Scale (Balducci et al., 2010) were used to assess employee engagement in their work. Finally, three items were used to assess intention to quit (Mobley et al., 1978). Table 1 shows the results of all item surveys alongside the standardized factor loading, average variance extracted (AVE), composite reliability (CR), and Cronbach's alpha as internal consistency reliability.

\section{Result and Discussion}

\subsection{Measurement Model}

The reliability, convergent validity, and discriminant validity of the study's items were all tested. All of the items used for this study are good indicators of the latent variables, according to the results. Also it was demonstrated that the measurement models meet all of the minimum requirements (Table 1). For factor loadings, a cut-off value of 0.708 significance (t-value $>1.96$ and p-value 0.05 ) was employed. All of the items in this analysis had loadings greater than 0.729. According to Hair, Ringle, and Sarstedt (2011 \& 2013), 
higher outer loading factors indicate greater indication reliability. In addition, when Dijkstrarho Henseler's (rhoA) is used instead of Cronbach's alpha and Composite Reliability, a more precise evaluation of data consistency is obtained. The values here indicate the dependability of the objects loaded on each construct (Ringle et al., 2017). Furthermore, because Cronbach's Alpha has a lower bound value, causing genuine reliability to be underestimated, some researchers decided to adopt Composite Reliability (CR) (Peterson \& Kim, 2013). In reality, $\mathrm{CR}$ can be used as an alternative to Cronbach's Alpha because of its somewhat greater value in contrast to that of the latter, with a relatively insignificant difference between them (Peterson \& Kim, 2013). In this investigation, the CR values are greater than the recommended threshold value of 0.708. (Hair et al., 2013; Henseler, Ringle \& Sinkovics, 2009; Wong, 2013). Meanwhile, all average variance extracted (AVE) values are greater than the 0.50 criterion. In terms of convergent validity, this backs up the concept measures (Henseler, 2017; Henseler, Hubona, \& Ray, 2016).

Table 1. Scale items and construct evaluation

\begin{tabular}{|c|c|c|c|c|c|}
\hline Construct & Item & $\lambda$ & AVE & $\mathrm{CR}$ & A \\
\hline $\begin{array}{l}\text { Proactive } \\
\text { personality }\end{array}$ & & & 0.785 & 0.956 & 0.945 \\
\hline PP1 & If I see something I don't like, I fix it & 0.853 & & & \\
\hline PP2 & If I see something I don't like, I fix it & 0.890 & & & \\
\hline PP3 & $\begin{array}{l}\text { I love being a champion for my ideas, even } \\
\text { against others' opposition. }\end{array}$ & 0.865 & & & \\
\hline PP4 & I am always looking for better ways to do things & 0.903 & & & \\
\hline PP5 & $\begin{array}{l}\text { If I believe in an idea, no obstacle will prevent } \\
\text { me from making it happen. }\end{array}$ & 0.898 & & & \\
\hline $\begin{array}{l}\text { Job } \\
\text { autonomy }\end{array}$ & & & 0.750 & 0.900 & 0.833 \\
\hline JA1 & $\begin{array}{l}\text { I have made my own decision about how to } \\
\text { schedule my work }\end{array}$ & 0.851 & & & \\
\hline JA2 & $\begin{array}{l}\text { I have made decisions about what methods I } \\
\text { would use to complete my work. }\end{array}$ & 0.866 & & & \\
\hline JA3 & $\begin{array}{l}\text { I have had a chance to use my personal } \\
\text { initiative or judgment in carrying out my work }\end{array}$ & 0.880 & & & \\
\hline $\begin{array}{l}\text { Work } \\
\text { engagement }\end{array}$ & & & 0.752 & 0.965 & 0.958 \\
\hline EE1 & At my work, I feel bursting with energy. (Vigor) & 0.784 & & & \\
\hline EE2 & At my job, I feel strong and vigorous. (Vigor) & 0.826 & & & \\
\hline EE3 & $\begin{array}{l}\text { When I get up in the morning, I feel like going } \\
\text { to work. (Vigor) }\end{array}$ & 0.847 & & & \\
\hline EE4 & I am enthusiastic about my job. (Dedication & 0.857 & & & \\
\hline EE5 & My job inspires me. (Dedication) & 0.899 & & & \\
\hline EE6 & I am proud of the work that I do. (Dedication) & 0.893 & & & \\
\hline EE7 & $\begin{array}{l}\text { I feel happy when I am working intensely. } \\
\text { (Absorption) }\end{array}$ & 0.900 & & & \\
\hline
\end{tabular}




\begin{tabular}{llllll} 
EE8 & I am immersed in my work. (Absorption) & 0.890 & & \\
EE9 & $\begin{array}{l}\text { I get carried away when I am working. } \\
\text { (Absorption) }\end{array}$ & & 0.899 & & \\
\hline $\begin{array}{l}\text { Intention to } \\
\text { quit }\end{array}$ & & 0.564 & 0.837 & 0.752 \\
IQ1 & $\begin{array}{l}\text { I intend to look for a job outside of [company } \\
\text { name] within the next year. }\end{array}$ & & & \\
IQ2 & $\begin{array}{l}\text { I intend to remain with [company name]. } \\
\text { (Reverse-coded) }\end{array}$ & & & \\
IQ3 & $\begin{array}{l}\text { I often think about quitting my job at [company } \\
\text { name]. }\end{array}$ & & & \\
\hline
\end{tabular}

Note: $\lambda=$ standardized factor loading; $\mathrm{AVE}=$ average variance extracted; $\mathrm{CR}=$ composite reliability; $\alpha=$ Cronbach's alpha. All factor loadings are significant $(\mathrm{p}<0.001)$. The values of Cronbach's alpha for three subdimensions of the UWES-9 are 0.88 (vigor), 0.81 (dedication), and 0.87 (absorption)

Table 2 Path Coefficient

\begin{tabular}{lrrr}
\hline & $\begin{array}{c}\text { (Path Coefficient) } \\
\mathbf{F}^{\mathbf{2}}\end{array}$ & IQ & \\
\hline Employee engagement & EE & $0.052, \mathbf{( - 0 . 3 6 7 )}$ & 0.734 \\
Job autonomy & & & \\
Proactive Behavior & $0.067,(\mathbf{0 . 1 5 5})$ & $0.01, \mathbf{( - 0 . 1 6 2 )}$ & \\
Intention to quit & $1.63,(\mathbf{0 . 7 6 7})$ & & 0.261 \\
\hline
\end{tabular}

The study's discriminant validity was assessed using three methods: first, the Fornell-Larcker criterion, as proposed by Hair et al. (2013) as the standard method for analyzing this type of validity. The HTMT test, as demonstrated by Henseler, Ringle, and Sarstedt (2015), is the second technique, and the third method is to determine whether each indication outer loading on the appropriated construct is greater than cross-loadings with other constructions (Farrell, 2010; Obeid, Salleh \& Mohd. Nor, 2017). In comparison to the use of other standard methodologies, the HTMT method was used at this stage as a tighter requirement. All variables meet the Fornell-Larcker criterion, as evidenced by the findings. The square root of each AVE, in particular, is greater than the correlations between constructs and reflective items (Hair et al., 2013; Henseler et al., 2016). Furthermore, the heterotrait-monotrait (HTMT) values in each example are smaller than the 0.85 criterion recommended by Hair et al. (2017) and Henseler et al (2015). Table 2 shows the results, which show that there is discriminant validity. 
Table 3 Discriminant Validity

\begin{tabular}{llrlrl}
\hline & $\begin{array}{l}\text { Employee } \\
\text { Engage }\end{array}$ & \multicolumn{2}{l}{$\begin{array}{l}\text { Job } \\
\text { Autonomy }\end{array}$} & $\begin{array}{l}\text { Proactive } \\
\text { Behaviour }\end{array}$ & \multicolumn{2}{l}{$\begin{array}{l}\text { Intention to } \\
\text { Quit }\end{array}$} \\
\hline Employee Engage & & 0.867 & & & \\
Job Autonomy & 0.548 & 0.866 & & & \\
Proactive & & & & 0.886 & \\
Behaviour & 0.846 & 0.512 & -0.472 & 0.751 \\
Intention to Quit & -0.504 & -0.086 & & & \\
\hline
\end{tabular}

Table 4 HTMT

\begin{tabular}{lllll}
\hline & $\begin{array}{l}\text { Employee } \\
\text { Engage }\end{array}$ & $\begin{array}{l}\text { Job } \\
\text { Autonomy }\end{array}$ & $\begin{array}{l}\text { Proactive } \\
\text { Behaviour }\end{array}$ & $\begin{array}{l}\text { Intention to } \\
\text { Quit }\end{array}$ \\
\hline $\begin{array}{l}\text { Employee Engage } \\
\text { Job Autonomy }\end{array}$ & 0.61 & & & \\
Proactive & & & & \\
Behaviour & 0.884 & 0.576 & & \\
Intention to Quit & 0.554 & 0.171 & 0.52 & \\
\hline
\end{tabular}
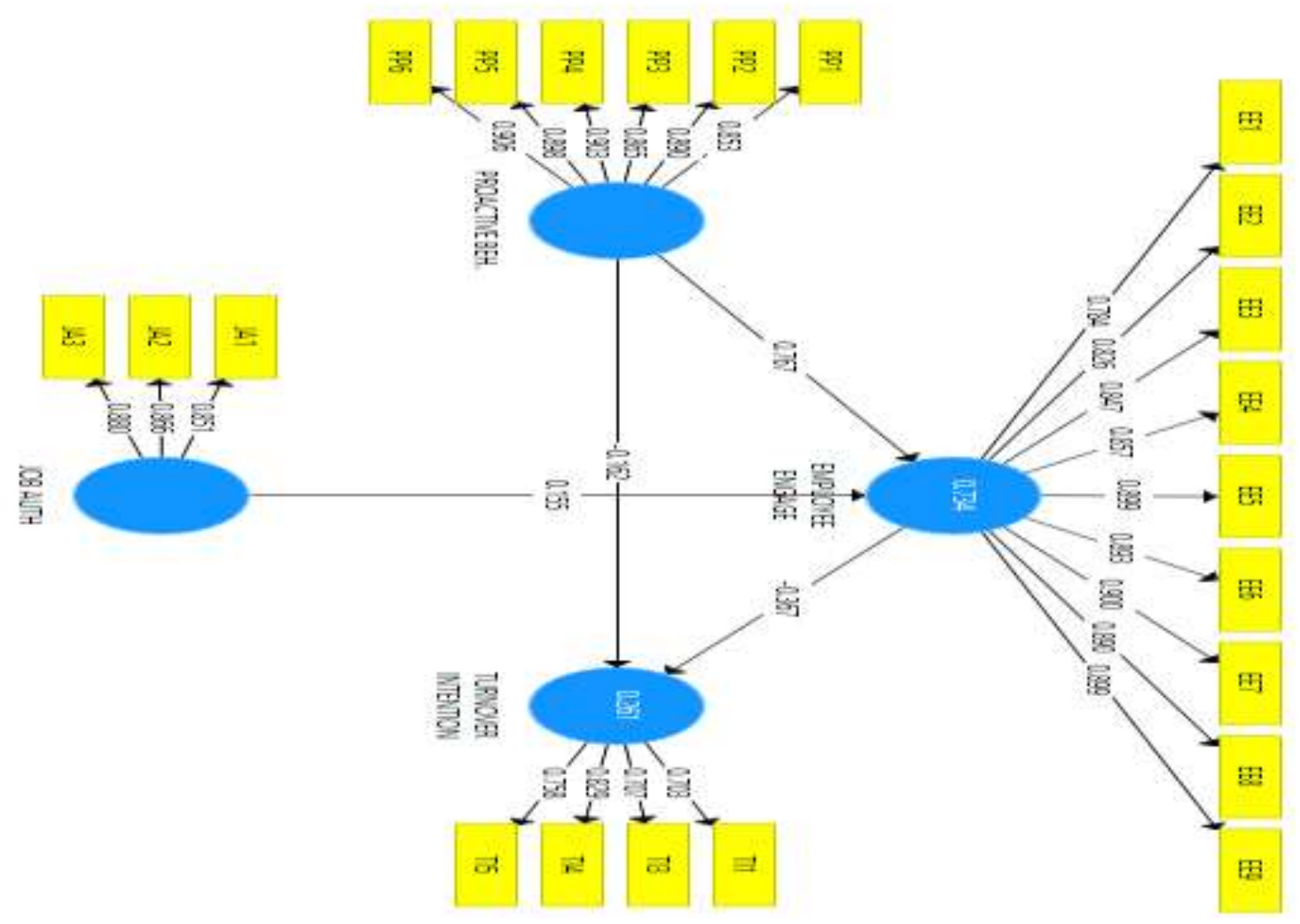

Figure 2 Measurement Model

Publisher by: 
Table 5 Path Coefficient

\begin{tabular}{|c|c|c|c|c|c|}
\hline PATH & $\begin{array}{l}\text { STD. } \\
\text { BETA }\end{array}$ & $\begin{array}{c}\text { STD } \\
\text { ERROR }\end{array}$ & $\begin{array}{c}\mathrm{T} \\
\text { Value } \\
\mathrm{S}\end{array}$ & $\begin{array}{c}\mathrm{P} \\
\text { Value } \\
\mathrm{S}\end{array}$ & $\begin{array}{c}\text { DECISIO } \\
\mathrm{N}\end{array}$ \\
\hline EMPLOYEE ENGAGEMENT -> TURNOVER & & & & & SUPPOR \\
\hline INTENTION & -0.387 & 0.093 & 4.17 & 0.000 & $\begin{array}{c}\text { TED } \\
\text { SUPPOR }\end{array}$ \\
\hline JOB AUTH -> EMPLOYEE ENGAGEMENT & 0.315 & 0.04 & 7.788 & 0.000 & TED \\
\hline PROACTIVE BEH. -> EMPLOYEE & & & 27.53 & & SUPPOR \\
\hline ENGAGEMENT & 0.756 & 0.027 & 7 & 0.000 & $\begin{array}{c}\text { TED } \\
\text { NOT } \\
\text { SUPPOR }\end{array}$ \\
\hline PROACTIVE BEH. -> TURNOVER INTENTION & -0.128 & 0.097 & 1.317 & 0.189 & TED \\
\hline PROACTIVE*WORK ENGAGEMENT -> & & & & & SUPPOR \\
\hline EMPLOYEE ENGAGEMENT & 0.264 & 0.03 & 8.763 & 0.000 & TED \\
\hline
\end{tabular}

Table 6 Path Coefficient

\begin{tabular}{|c|c|c|c|c|c|c|}
\hline $\begin{array}{c}\mathrm{HY} \\
\mathrm{P}\end{array}$ & Path & $\begin{array}{l}\text { STD. } \\
\text { BETA }\end{array}$ & $\begin{array}{l}\text { STD } \\
\text { Error }\end{array}$ & $\begin{array}{c}\mathrm{T} \\
\text { Value } \\
\mathrm{s}\end{array}$ & $\begin{array}{c}\mathrm{P} \\
\text { Value } \\
\mathrm{S}\end{array}$ & Decision \\
\hline H1 & $\begin{array}{l}\text { Proactive Behaviour. -> Employee } \\
\text { Engage -> Intention to quit } \\
\text { Proactive*Work Engagement -> }\end{array}$ & -0.292 & 0.073 & 4.003 & 0.000 & Supported \\
\hline $\mathrm{H} 2$ & $\begin{array}{l}\text { Employee Engage -> Intention to } \\
\text { quit } \\
\text { Proactive*Work Engagement -> }\end{array}$ & -0.102 & 0.023 & 4.408 & 0.000 & Supported \\
\hline $\mathrm{H} 3$ & Employee Engagement & 0.264 & 0.03 & 8.763 & 0.000 & Supported \\
\hline
\end{tabular}

Following the evaluation of the measurement model, this study used the bootstrapping approach to investigate the link between exogenous and endogenous latent constructs. The significance results of the independent and dependent variables were displayed in Figure 3. All of the independent variables, such as proactive personality $(=.367, \mathrm{p} .001)$, employee engagement $(=.227, \mathrm{p} .001)$, and job autonomy $(=.291, \mathrm{p} .001)$, had significant and positive correlations with intention to resign, according to the findings (see Table 4). As a result, H1, $\mathrm{H} 2$, and $\mathrm{H} 3$ are all supported. 


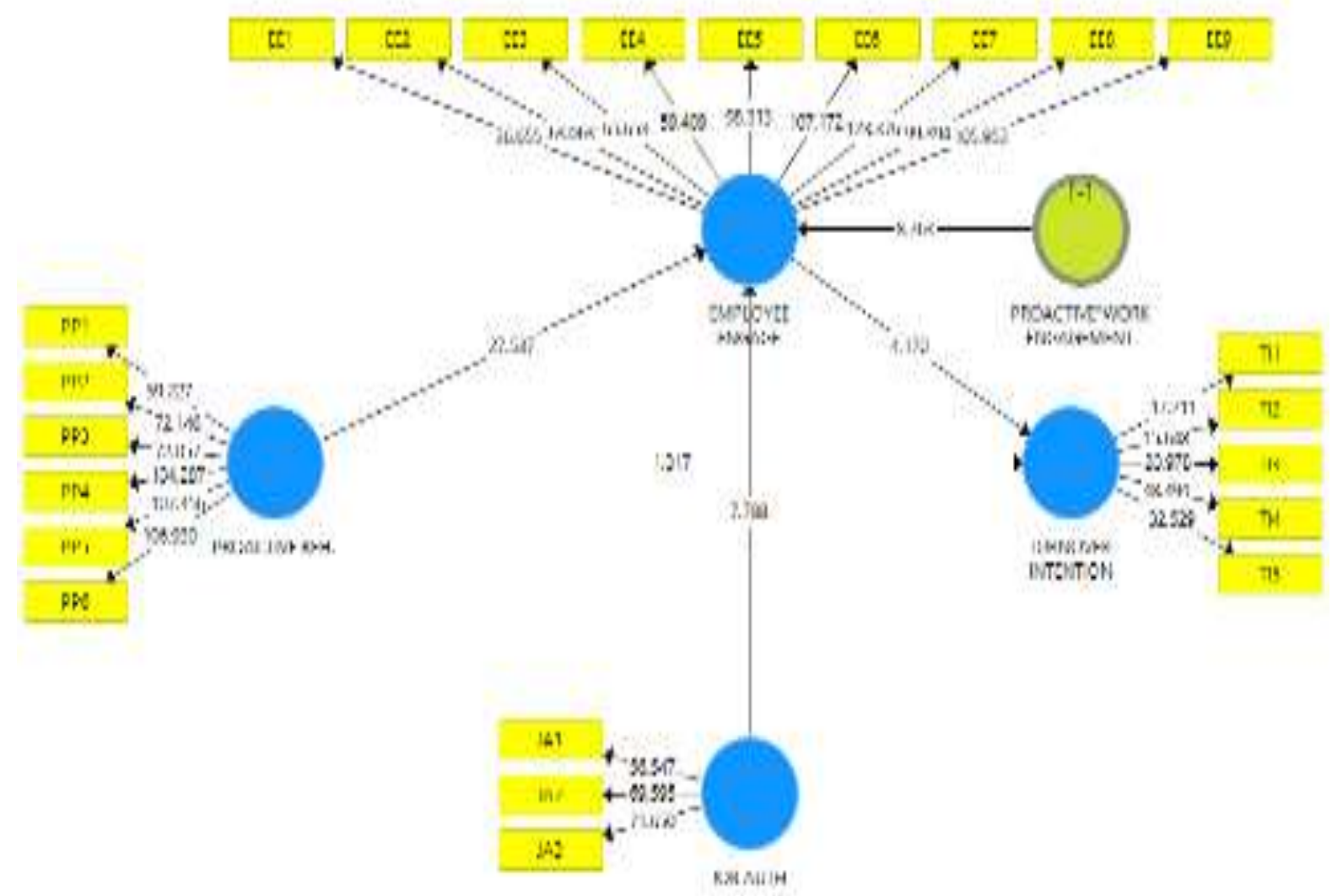

Figure 4 Structural Model

This study used a two-stage strategy using Smart PLS structural equation path modeling to analyze the moderating influence of job autonomy between proactive PP and intention to quit so as to investigate the moderator effect. The current study suggested that JA can regulate the link between PP and intention to quit, with more job autonomy resulting in a stronger relationship than lower job autonomy. Table 4 and Figure 4 demonstrate that JA*EE $(=.156$, p.001) and POS*JS (=.131, p.001) have substantial and favorable interaction effects on intention to quit. As a result, hypotheses $\mathrm{H} 5$ and $\mathrm{H} 6$ are supported.

The variations explained by the exogenous latent constructs in the measurement model were also investigated in this study. According to Chin (1998), the $\mathrm{R}^{2}$ number should range from zero to one. Cohen (1988) suggested that $\mathrm{R}^{2}$ values of $0.02,0.13$, and 0.26 be regarded as weak, moderate, and substantial, respectively. Based on Cohen's (1988) threshold value, the $\mathrm{R}^{2}$ value in Figure 2 indicates that the endogenous latent construct may be described by the endogenous latent constructs with a large (.506 percent) variance.

The findings of the PLS bootstrapping to explore mediation, moderation, and moderated mediation are presented in Table 4. Work engagement, according to Hypothesis 1, was a mediator between PP and intention to quit. In Table 4, Figure 3 shows a significant negative main connection between PP and intention to quit $(=0.18, t=2.28, \mathrm{p} 0.05)$. Figure 3 shows a substantial positive link between PP and work engagement $(=0.48, t=6.80, \mathrm{p} 0.001)$. Figure 3 shows that, when proactive personality was controlled, WE had a considerably negative 
association with intention to quit $(=0.491, \mathrm{t}=6.292, \mathrm{p} 0.001)$, but proactive personality and intention to quit had no relationship $(=0.06, \mathrm{t}=0.71, \mathrm{p}>0.05)$. Established previous researchers such as Baron and Kenny's (1986) classical approach, this is a predictable display of full mediation.

To more thoroughly test the mediation outcome, confidence intervals (CI) of indirect impact were generated and bootstrapping. Table 5 summarizes the findings. Based on 5000 bootstrapped resampling, the indirect effect of work engagement was significant $(b=0.38,95$ percent bias-corrected $\mathrm{CI}=[0.561,0.242])$, whereas the direct effect was not $(b=0.09,95$ percent bias-corrected $\mathrm{CI}=[0.162,0.3391])$. The study based on 1000 repetitions of the simulated distribution revealed the same result $(b=0.399,95$ percent $C I=[0.553,0.232])$. In conclusion, the role of WE as a complete mediator between PP and intention to quit has been properly established. As a result, Hypothesis 1 was shown to be true.

Continuous independent variables were mean-centered prior to testing moderation and moderated mediation to eliminate the possibility of multicollinearity (Saunders et al., 2009). The variance inflation factor (VIF) values in all of the regression models were less than 1.80, which is a reasonable level.

Hypothesis 2 proposed that the extent of JA moderates the link between PP and WE. The interaction term of PP and job autonomy was significant $(=0.13, \mathrm{t}=2.01, \mathrm{p} 0.051)$, as shown in Figure 3 in Table 4. Furthermore, as shown in Table 4, the bootstrapping test showed a significant interaction effect $(b=0.253,95 \%$ bias-corrected $C I=[0.00473,0.502])$. The basic slope test (Stevens, 2009) revealed that when job autonomy was high $(+1 \mathrm{SD})$, the positive association between PP and WE was substantially greater $(b=0.651, t=5.493, p 0.0012)$. When JA was low (one standard deviation), the connection was weak $(b=0.312, t=2.331, p$ 0.051). As a result, $\mathrm{H} 2$ was shown to be true. Figure 4 depicts the slope difference at one standard deviation of job autonomy.

Hypothesis 3 contends that the level of JA moderates the mediation effect between PP and desire to quit via WE. The extent of an indirect impact via mediator fluctuates dramatically varying on the degree of the moderator in moderated mediation. Under two conditions, it can be ascertained that there is a moderated mediation effect in the model of this study: (1) if the link between PP and WE(for example, mediator) is moderated by JA (for example, moderator), and (2) if the relationship between work engagement (for example, mediator) and intention to quit remains significant in the model including the interaction (i.e., moderator). By accepting Hypothesis 2, the first requirement was already met. Work engagement was strongly related to intention to quit in the second condition $(=0.491, \mathrm{t}=5.691, \mathrm{p} 0.001)$ (Figure 3 in Table 4). As a result, it is possible to conclude that there is a moderated mediation effect. 


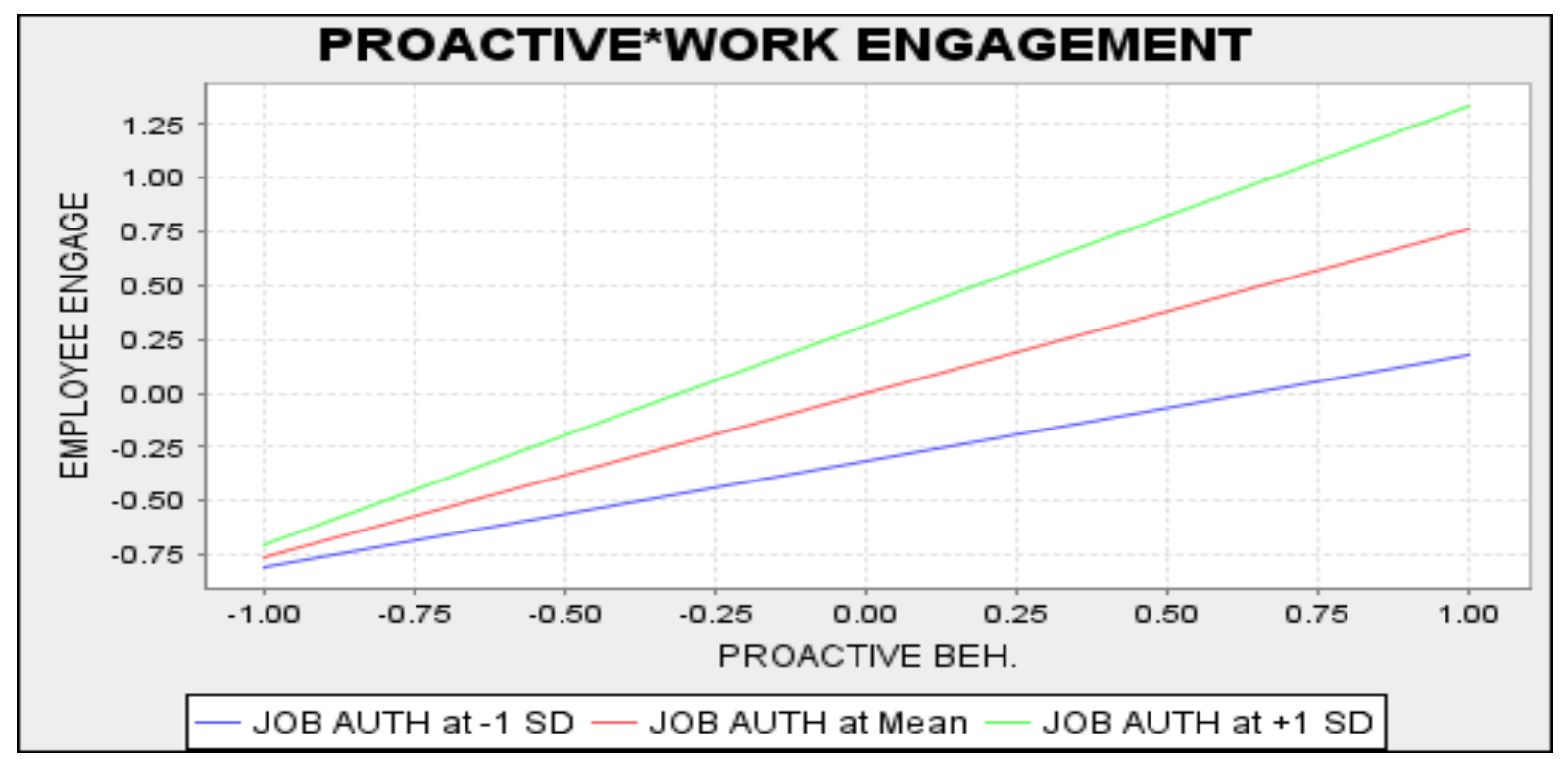

Figure 5 Moderation

\subsection{Discussion}

We believe that existing research on proactive employees' intentions to quit has two unresolved concerns. First, no theoretical framework explains how proactive personality affects quitting intentions. Second, the relationship's empirical outcomes have been inconsistent. The current study focuses on a research framework that integrates the motivational mediator and the appropriate moderator in the association between PP and intention to quit in order to fill these research gaps. This research aimed to see if WE mediates the relationship between PP and intention to quit, if JA moderates the relationship between PP and WE, and if JA moderates the mediated relationship between PP and intention to quit through WE. In addition, we discovered that WE act as intermediate function in relating PP with intention to quit utilizing survey data from 420 health workers working for a teaching hospital in Nigeria's north central region. In addition, job autonomy appears to play a role in explaining the favorable relationship between proactive personality and work engagement, according to this research. Conclusively, the findings of the current study revealed that job autonomy moderates the indirect relationship between PP and the intention to resign through WE.

\subsubsection{Theoretical contributions and practical implications}

Researchers generally believe that proactive individuals who are probable to become high achievers are critical for contemporary corporate organizations' survivability (Bergeron et al., 2013; Elsaied, 2019). They have, however, failed to rationally clarify and experimentally explain the relationship between PP, which signifies employee proactive tendencies, and intention to quit, which is used to forecast actual turnover. This study contributes to the relevant literature by attempting to resolve these challenges.

Work engagement, in particular, appears to act as a relationship between PP and intention to quit, according to this study. It is crucial to investigate the intermediary mechanism that mediates the link between PP and intention to quit in order to fully recognize the underlying 
nature of the link (Kundu \& Gahlawat, 2016). The researchers concentrated on WE because it is a motivational variable that is closer to intention to quit. We used the distal-proximal method, which states that proximal motivational states indirectly link to distal dispositional tendencies (Barrick \& Mount, 2005). Work engagement has been presented as a precursor of behavioral intent or a result of employee personality in previous studies (Christian, Garza, \& Slaughter, 2011; Saks, 2006). The current research emphasizes the significance of WE as a relationship in justifying the association between PP and intention to quit by going beyond previous research. Work involvement, in particular, appears to entirely moderate the connection between proactive personalities and intention to quit. This conclusion shows that individuals with proactive personalities are more interested in their jobs, which leads to a lower likelihood of quitting. It also implies that proactive employees who have the capacity of good behavior are more expected to value their employers.

Furthermore, we aimed to investigate the work setting that could hypothetically increase the proactive trait, based on trait activation theory (Tett \& Burnett, 2003), which states that traits are exhibited as answers to pertinent situational signals. Indeed, the association between proactive dispositional propensity and employee motivational state is dependent on the selfdirected employment situation, according to this study. As a result, this research supports the theory's validity while also expanding its applicability. . The findings of this study, on the other hand, are significant because they respond to a request for research into the amount to which situational variables boost or dampen the sign of PP (Bateman \& Crant, 2017). The current paper highlights JA as a significant border circumstance to establish the boundary to which PP interacts with WE by unearthing that high degrees of JA seem to strengthen the favorable relationship between PP and WE. As a result, this research adds to the proactivity literature by identifying the best related element that might work in tandem with an individual's proactive personality.

Finally, using the job demands-resources model of work engagement (Hoole \& Bonnema, 2015), we built a moderated meditation framework to justify for the relationship between PP and intention to quit (Rana et al., 2014). We also found that when proactive individuals complete independent activities, they are further expected to get engaged with their job, which reduces their desire to leave. This research adds to our knowledge of how PP affects intention to quit and when proactive employees' intention to quit declines. Furthermore, the study methodology of this research supports Blumberg and Pringle's (1982) claim that in order to explain employee behavior, researchers must investigate individual ability, opportunity, and motivation. In support of this theory, we discovered evidence that the behavioral intention (i.e., intention to leave) is controlled by the motivation (i.e., work engagement) that results from the combined strength of the ability (for example, proactive personality) and the opportunity (for example, opportunity to quit) (for example, job autonomy).

This research also has suggestions for effective organizational management. The implications for the staff, based on the findings of this study, include emphasizing the value of selecting proactive workers and measures to reduce proactive employee turnover. For today's commercial organizations, techniques to analyze candidates' proactivity may be beneficial and important. Given that proactive personality has a good relationship with job engagement and a negative link with intention to quit, it is beneficial to use the tools to discover proactive tendencies in applicants throughout the selection process. Following the recruitment of 
proactive employees, organizations must focus on developing organizational practices, such as education and training, as well as organizational culture, such as organizational and supervisor support, in order to increase workers' levels of engagement at work (Yongxing et al., 2017). (Saks, 2019). The degree of job autonomy is particularly important when creating job duties and assigning them to employees. As a result, firms should allow employees to work under autonomous working conditions that allow them to realize the benefits of their proactivity, reducing turnover among proactive personnel.

\subsection{Limitations and Future Research Directions}

Although the reality that this work makes significant theoretical and practical advances, it also has a number of drawbacks that will need to be addressed in the future. Because we used cross-sectional data to evaluate our research model, the causality of our findings cannot be ensured. Though it is not expected that intention to quit has a direct impact on proactive personality and job autonomy, longitudinal data should be used to validate the research framework and make the findings of this study more appealing. Given that motivation triggers behavior, we concentrated on WE as a primary mediator in this study to elucidate the influence of PP on intention to quit. Other elements, beyond from motivation, must be explored to better comprehend the correlation between qualities and behaviors.

\section{Conclusions}

Establishments are pushed to attract employees with proactive traits, and the personnel are frequently asked to perform in a practical way, given the turbulent changes in the business environment. Attempts to keep these crucial individuals from departing are critical. The current paper adds to these attempts by revealing that proactive health workers are initially engaged in their job and then have low intentions to quit. Furthermore, when individuals work in autonomous working environments, they are further engaged and their intention to quit is lower. Therefore, this research recommends that to retain proactive personnel in Nigeria's university teaching hospitals, greater emphasis should be placed on WE, a motivation and health-related indicator, and JA, a typical job attribute (Najam et al., 2018; (Gadi \& Kee, 2020b; Albadayneh \& Alrawashdeh, 2017)

\section{REFERENCES}

Abdulrab, M., Zumrah, A. R., Almaamari, Q., \& Altahitah, A. (2017). The role of psychological empowerment on work engagement: The development of conceptual framework. International Journal of Business Management and Economic Research, 8(6), 1157-1163.

Achmad, A., Fernandes, R., \& Taba, I. M. (2019). Welding technology as the moderation variable in the relationships between government policy and quality of human resources and workforce competitiveness. Journal of Science and Technology Policy Management, 10(1), 58-72. https://doi.org/10.1108/JSTPM-05-2017-0019

Albadayneh, G., \& Alrawashdeh, E. T. (2017). The impact of Intellectual Capital on the Organizational Citizenship Behavior ( OCB ) in Business Organizations : Field Study 
on the Jordanian Industrial Companies. International Journal of Business Management and Economic Research, 8(4), 987-997.

Albrecht, S. L., Bakker, A. B., Gruman, J. A., Macey, W. H., Saks, A. M., Albrecht, S. L., Bakker, A. B., Gruman, J. A., Macey, W. H., Saks, A. M., \& Albrecht, S. L. (2015). Employee engagement, human resource management practices and competitive advantage an integrated approach. Journal of Organizational Effectiveness: People and Performance, 2(1), 7-35. https://doi.org/10.1108/JOEPP-08-2014-0042

Allen, D. G., Weeks, K. P., \& Moffitt, K. R. (2005). Turnover Intentions and Voluntary Turnover: The Moderating Roles of Self-Monitoring, Locus of Control, Proactive Personality, and Risk Aversion. Journal of Applied Psychology, 90(5), 980-990. https://doi.org/10.1037/0021-9010.90.5.980

Bakker, A. B. (2011). An Evidence-Based Model of Work Engagement. Current Directions in Psychological Science, 20(4), 265-269. https://doi.org/10.1177/0963721411414534

Bakker, A. B. (2017). Strategic and proactive approaches to work engagement. Organizational Dynamics, 46(2), 67-75. https://doi.org/10.1016/j.orgdyn.2017.04.002

Bakker, A. B., \& Albrecht, S. (2018). Work engagement: current trends. Career Development International, 12(15), 5173-5180. https://doi.org/10.1108/CDI-11-2017-0207

Bakker, A. B., Tims, M., \& Derks, D. (2012). Proactive personality and job performance: The role of job crafting and work engagement. Human relations, 65(10), 1359-1378.

Bakker, A.B. and Demerouti, E. (2008), "Towards a model of work engagement", Career Development International, Vol. 13 No. 3, pp. 209-223. https://doi.org/10.1108/13620430810870476

Balducci, C., Fraccaroli, F., \& Schaufeli, W. B. (2010). Psychometric Properties of the Italian Version of the Utrecht Work Engagement Scale ( UWES-9 ). European Journal of Psychological Assessment, 26(2), 143-149. https://doi.org/10.1027/1015$5759 / \mathrm{a} 000020$

Barrick, M. R., Shaffer, J. A., \& DeGrassi, S. W. (2009). What you see may not be what you get: Relationships among self-presentation tactics and ratings of interview and job performance. Journal of Applied Psychology, 94(6), 1394-1411. https://doi.org/10.1037/a0016532

Bateman T. S. \& Crant J. M. (1993). The Proactive Component of Organizational Behavior: A Measure and Correlates. Journal of Organizational Behavior 14(2):103 - 118

Beehr, T. A., Glaser, K. M., Canali, K. G., \& Wallwey, D. E. E. A. (2001). Back to basics : Re-examination of Demand- Control Theory of occupational stress. Work \& Stress, 15(2), 115-130. https://doi.org/10.1080/02678370110067002

Bergeron, D. M., Schroeder, T. D., \& Martinez, H. A. (2013). Proactive Personality at Work: Seeing More to Do and Doing More? Journal of Business Psychology, 2009. https://doi.org/10.1007/s10869-013-9298-5 
Brito, R. P. De, \& Oliveira, L. B. De. (2016). The Relationship Between Human Resource Management and Organizational Performance. Brazilian Business Review, 13(3), 90-110. https://doi.org/http://dx.doi.org/10.15728/bbr.2016.13.3.5

Caponecchia, C., Branch, S., \& Murray, J. P. (2020). Development of a Taxonomy of Workplace Bullying Intervention Types: Informing Research Directions and Supporting Organizational Decision Making. Group \& Organization Management, 45(1), 103-133. https://doi.org/10.1177/1059601118820966

Chin, W. W. (1998). The partial least squares approach to structural equation modeling. In G. A. Marcoulides (Ed.), Modern methods for business research (pp. 295-336) Mahwah: Lawrence Erlbaum.

Christian, M. S., Garza, A. S., \& Slaughter, J. E. (2011). Work engagement : A quantitative review and test of its relations with task and contextual Performance. Personnel Psychology, 64, 89-136.

Cohen, J. (1988). Statistical power analysis for the behavioral sciences (2nd ed.). Hillsdale: Lawrence Erlbaum Associates.

De Gieter, S., Hofmans, J., \& Bakker, A. B. (2018). Need satisfaction at work, job strain, and performance: A diary study. Journal of Occupational Health Psychology, 23(3), 361372. https://doi.org/10.1037/ocp0000098

Elsaied, M. M. (2019). Supportive leadership , proactive personality and employee voice behavior. American Journal of Business, 34(1), 2-18. https://doi.org/10.1108/AJB01-2017-0004

Fabi, B., Lacoursière, R., \& Raymond, L. (2015). Impact of high-performance work systems on job satisfaction, organizational commitment, and intention to quit in Canadian organizations. International Journal of Manpower, 36(5), 772-790. https://doi.org/10.1108/IJM-01-2014-0005

Farrell, A.M. (2010), "Insufficient Discriminant Validity: A Comment on Bove, Pervan, Beatty, and Shiu (2009)", Journal of Business Research, Vol. 63, pp. 324-327.

Fuller, B., Jr., \& Marler, L. E. (2009). Change driven by nature: A meta-analytic review of the proactive personality literature. Journal of Vocational Behavior, 75(3), 329-345. https://doi.org/10.1016/j.jvb.2009.05.008

Gadi, P. D., \& Kee, D. M. H. (2020a). The buffering effect of perceived organizational support on the relationship linking work engagement and turnover intention. Asia Proceedings of Social Sciences (APSS), 6(2), 108-111.

Gadi, P. D., \& Kee, D. M. H. (2020b). Workplace bullying, human resource management practices, and turnover intention: the mediating effect of work engagement: evidence of Nigeria. American Journal of Business, 1935-5181. https://doi.org/10.1108/AJB-08-2020-0135

Griffeth, R. W., Hom, P. W., \& Gaertner, S. (2000). A meta-analysis of antecedents and correlates of employee turnover: Update, moderator tests, and research implications 
for the next millennium. Journal of Management, 26, 463- 488. doi: $10.1177 / 014920630002600305$

Gruman, J. A., \& Saks, A. M. (2011). Human Resource Management Review Performance management and employee engagement. Human Resource Management Review, 21(2), 123-136. https://doi.org/10.1016/j.hrmr.2010.09.004

Gupta, P. D., Bhattacharya, S., Sheorey, P., \& Coelho, P. (2018). Relationship between onboarding experience and turnover intention: intervening role of locus of control and self-efficacy. Industrial and Commercial Training, 50(2), 61-80. https://doi.org/10.1108/ICT-03-2017-0023

Hair, J. F. and Ringle, C. M. and Sarstedt, M., (2013). Editorial - Partial Least Squares Structural Equation Modeling: Rigorous Applications, Better Results and Higher Acceptance. Long Range Planning, Volume 46, Issues 1-2, pp. 1-12, Available at SSRN: https://ssrn.com/abstract=2233795

Hair, J.F., C.M. Ringle, \& M. Sarstedt, (2011) An assessment of the use of partial least squares structural equation modeling in marketing research. Journal of the Academy of Marketing Science 40, no. 3: 414-33.

Henseler, J., Hubona, G., \& Ray, P. A. (2016). Using PLS path modeling in new technology research: updated guidelines. Industrial management \& data systems.

Henseler, J., Ringle, C. M., \& Sarstedt, M. (2015). A new criterion for assessing discriminant validity in variance-based structural equation modeling. J. of the Acad.Mark. Sci., 115-135. https://doi.org/10.1007/s11747-014-0403-8

Henseler, J., Ringle, C., \& Sinkovics, R. (2009). The Use of Partial Least Squares Path Modeling in International Marketing. Advance in International Marketing, 20, 277319. http://dx.doi.org/10.1108/S1474-7979(2009)0000020014

Hobfoll, S. E., Johnson, R. J., Ennis, N., \& Jackson, A. P. (2003). Resource loss, resource gain, and emotional outcomes among inner city women. Journal of Personality and Social Psychology, 84(3), 632-643. https://doi.org/10.1037/0022-3514.84.3.632

Hoole, C., \& Bonnema, J. (2015). Work engagement and meaningful work across generational cohorts. SA Journal of Human Resource Management, 13(1), 1-11. https://doi.org/10.4102/sajhrm.v13i1.681

Ibrahim, S. N. H., Suan, C. L., \& Karatepe, O. M. (2019). The effects of supervisor support and self-efficacy on call center employees work engagement and quitting intentions. International Journal of Manpower. https://doi.org/10.1108/IJM-12-20170320

James, L. R., \& Brett, J. M. (1984). Mediators , Moderators , and Tests for Mediation. Journal of Applied Psychology, 69(2), 307-321.

Jiménez, R. E., Bachelet, V. C., Gomolán, P., Lefio, L. Á., \& Goyenechea, M. (2019). Violence and burnout in health care emergency workers in Santiago, Chile: A surveybased cross-sectional study. International emergency nursing, 47, 100792. 
Joe F. Hair, Christian M. Ringle \& Marko Sarstedt (2011) PLS-SEM: Indeed a Silver Bullet, Journal of Marketing Theory and Practice, 19:2, 139-152, DOI: 10.2753/MTP10696679190202

Kubayi, A. (2018). Burnout and Paths to Turnover Intentions among South African Sport Coaches. Monten. J. Sports Sci. Med, 7, 43-47. https://doi.org/10.26773/mjssm.180907

Kumdi, M. W., Gadi, D. P., \& Abbah, M. T. (2017). An evaluation of work performance culture among civil servants in Nigeria. Tax Academy Research Journal (TARJ), $1(1), 165-184$.

Kundu, S. C., \& Gahlawat, N. (2016). High performance work systems and employees' intention to leave: Exploring the mediating role of employee outcomes. Management Research Review, 39(12), 1587-1615. https://doi.org/10.1108/MRR-04-2015-0088

Lartey, J. K. S., Amponsah-Tawiah, K., \& Osafo, J. (2019). The moderating effect of perceived organizational support in the relationship between emotional labour and job attitudes: A study among health professionals. NursingOpen, July 2018, 990997. https://doi.org/10.1002/nop2.295

Mackenzie, S. B., \& Podsakoff, P. M. (2012). Common Method Bias in Marketing: Causes, Mechanisms , and Procedural Remedies. Journal of Retailing, 88(4), 542-555. https://doi.org/10.1016/j.jretai.2012.08.001

Malhotra, M. K., Singhal, C., Shang, G., \& Ployhart, R. E. (2014). Technical note A critical evaluation of alternative methods and paradigms for conducting mediation analysis in operations management research. Journal of Operations Management, 32(4), 127137. https://doi.org/10.1016/j.jom.2014.01.003

Mathieu, J.E. and Taylor, S.R. (2006), Clarifying conditions and decision points for mediational type inferences in Organizational Behavior. J. Organiz. Behav., 27: 1031-1056. https://doi.org/10.1002/job.406

Memon, M. A., Sallaeh, R., Baharom, M. N. R., Md Nordin, S., \& Ting, H. (2017). The relationship between training satisfaction, organisational citizenship behaviour, and turnover intention: A PLS-SEM approach. Journal of Organizational Effectiveness, 4(3), 267-290. https://doi.org/10.1108/JOEPP-03-2017-0025

Methot, J. R., Lepine, J. A., Podsakoff, N. P., \& Christian, J. S. (2016). Are Workplace Friendships a Mixed Blessing? Exploring Tradeoffs of Multiplex Relationships and their Associations with Job Performance. Personnel Psychology, 69(2), 311-355. https://doi.org/10.1111/peps.12109

Mobley, W. H., Horner, S. O., \& Hollingsworth, A. T. (1978). An Evaluation of Precursors of Hospital Employee Turnover. Journal of Applied Psychology, 63(4), 408-414.

Morgeson, F. P., \& Humphrey, S. E. (2006). The Work Design Questionnaire (WDQ): Developing and validating a comprehensive measure for assessing job design and the nature of work. Journal of Applied Psychology, 91(6), 1321-1339. https://doi.org/10.1037/0021-9010.91.6.1321 
Muldoon, J., Kisamore, J. L., Liguori, E. W., Jawahar, I. M., \& Bendickson, J. (2017). Moderators of the personality-performance relationship: An investigation of job meaning and autonomy. Personnel Review, 46(3), 474-489. https://doi.org/10.1108/PR-02-2016-0040

Najam U, Ishaque S, Shoukat S, Awan MH, Ansari NY. (2018). interactive effect of CCM between the relationship of work- place bullying, burnout, and turnover intentions. Cogent Bus Management, 5:1-13

Nawaz, M. S., Pangil, F., \& Bhatti, M. A. (2015). The Relationship between Human Resource Development Factors and Turnover Intention: A Conceptual Framework. International Journal of Academic Research in Business and Social Sciences, 5(12), 297-310. https://doi.org/10.6007/IJARBSS/v5-i12/1959

Obeid, M., Salleh, Z., \& Nor, M. N. M. (2017). The mediating effect of job satisfaction on the relationship between personality traits and premature sign-off. Academy of Accounting and Financial Studies Journal, 21(2), 1-17.

Podsakoff, P. M., Mackenzie, S. B., \& Podsakoff, N. P. (2012). Sources of Method Bias in Social Science Research and Recommendations on How to Control It. Annual Review. https://doi.org/10.1146/annurev-psych-120710-100452

Rai, A., Ghosh, P., \& Dutta, T. (2019). Total rewards to enhance employees' intention to stay: does perception of justice play any role? Evidence-Based HRM: A Global Forum for Empirical Scholarship, 7(3), 262-280. https://doi.org/10.1108/EBHRM07-2018-0045

Rana, S., Ardichvili, A., \& Tkachenko, O. (2014). A theoretical model of the antecedents and outcomes of employee engagement Dubin's method. Journal of Workplace Learning, 26(3), 249-266. https://doi.org/10.1108/JWL-09-2013-0063

Ringle, A., Dornhorst, A., Rehman, M. B., Ruisanchez, C., \& Nihoyannopoulos, P. (2017). Evolution of subclinical myocardial dysfunction detected by two-dimensional and three-dimensional speckle tracking in asymptomatic type 1 diabetic patients: a long-term follow-up study, Endocrine-Related Cancer, 4(4), 73-81. Retrieved Dec 14, 2021, from https://erp.bioscientifica.com/view/journals/echo/4/4/ERP-17$\underline{0052 . x m l}$

Saks, A. M. (2019). Antecedents and consequences of employee engagement revisited. Journal of Organizational Effectiveness: People and Performance, 6(1), 19-38. https://doi.org/10.1108/JOEPP-06-2018-0034

Saunders, M., Lewis, P., \& Thornhill, A. (2009). Research Methods for business students (fifth edit). Prentice Hall.

Schaufeli, W.B., Taris, T.W. and Van Rhenen, W. (2008), Workaholism, Burnout, and Work Engagement: Three of a Kind or Three Different Kinds of Employee Well-being?. Applied Psychology, 57: 173-203. $\quad$ https://doi.org/10.1111/j.14640597.2007.00285.x 
Seibert, S. E., Kraimer, M. L., \& Crant, J. M. (2001). What do proactive people do? A longitudinal model linking proactive personality and career success. In personnel psychology (Vol. 54).

Sheehan, C., Tham, T. L., Holland, P., Cooper, B., Sheehan, C., \& Holland, P. (2019). Psychological contract fulfilment, engagement and nurse professional turnover intention. International Journal of Manpower, 9(3), 212-228. https://doi.org/10.1108/IJM-08-2017-0211

Simon, L., Arnold, B., Jamie, A., William, H., \& Alan, M. (2015). Employee engagement, human resource management practices and competitive advantage An integrated approach. Journal of Organizational Effectiveness, 2(1), 7-35.

Singh, M., \& James, P. S. (2016). Antecedents and consequence of work engagement: A literature review. International Journal of Applied Business and Economic Research, 14(12), 8635-8656. https://doi.org/10.1108/02683940610690169

Stevens, B. (2009), "Corporate ethical codes: effective instruments for influencing behavior", Journal of Business Ethics, Vol. 78 No. 4, pp. 601-609.

Tett, R. P., \& Burnett, D. D. (2003). A personality trait-based interactionist model of job performance. Journal of Applied Psychology, 88(3), 500-517. https://doi.org/10.1037/0021-9010.88.3.500

This is an open-access article distributed under the terms and conditions of the Creative Commons Attribution license (http://creativecommons.org/licenses/by/4.0/)

Tummers, L., Kruyen, P. M., Vijverberg, D. M., \& Voesenek, T. J. (2015). Connecting HRM and change management: the importance of proactivity and vitality. Journal of Organizational Change Management, 28(4), 627-640. https://doi.org/10.1108/JOCM-11-2013-0220

Tziner A. \& Birati, A (1996) Assessing employee turnover costs: A revised approach. Human Resource Management Review 6(2):113-122. 10.1016/S1053-4822(96)90015-7

Ugwu, F. O., Onyishi, I. E., \& Tyoyima, W. A. (2013). Exploring the Relationships Between Academic Burnout, Self- Efficacy and Academic Engagement Among Nigerian College Students. The African Symposium: An Online Journal of the African Educational Research Network The African Symposium: An Online Journal of the African Educational Research Network, 13(2), 37-45.

Vandenberghe, C. and Basak Ok, A. (2013), "Career commitment, proactive personality, and work outcomes: a cross-lagged study", Career Development International, Vol. 18 No. 7, pp. 652-672. https://doi.org/10.1108/CDI-02-2013-0013

Vermooten, Nicola, Boonzaier, Billy, \& Kidd, Martin. (2019). Job crafting, proactive personality and meaningful work: Implications for employee engagement and turnover intention. SA Journal of Industrial Psychology, 45(1), 113. https://dx.doi.org/10.4102/sajip.v45i0.1567

Wang, G., Oh, I.-S., Courtright, S. H., \& Colbert, A. E. (2011). Transformational Leadership and Performance Across Criteria and Levels: A Meta-Analytic Review of 25 Years 
of Research. Group \& Organization Management, 36(2), 223-270. https://doi.org/10.1177/1059601111401017

Yang, K., Yan, X., Fan, J., \& Luo, Z. (2017). Leader-follower congruence in proactive personality and work engagement: A polynomial regression analysis. 105, 20162018.

Yongxing, G., Hongfei, D., Baoguo, X., \& Lei, M. (2017). Work engagement and job performance: the moderating role of perceived organizational support. Anales de Psicología, 33(3), 708. https://doi.org/10.6018/analesps.33.3.238571

\section{Copyrights}

Copyright for this article is retained by the author(s), with first publication rights granted to the journal.

This is an open-access article distributed under the terms and conditions of the Creative Commons Attribution license (http://creativecommons.org/licenses/by/4.0/) 